NBER WORKING PAPER SERIES

\title{
SIX CHALLENGES IN DESIGNING EQUITY-BASED PAY
}

\author{
Brian J. Hall \\ Working Paper 9887 \\ http://www.nber.org/papers/w9887 \\ NATIONAL BUREAU OF ECONOMIC RESEARCH \\ 1050 Massachusetts Avenue \\ Cambridge, MA 02138 \\ July 2003
}

The views expressed herein are those of the authors and not necessarily those of the National Bureau of Economic Research.

(C2003 by Brian J. Hall. All rights reserved. Short sections of text, not to exceed two paragraphs, may be quoted without explicit permission provided that full credit, including $(\subset$ notice, is given to the source. 
Six Challenges in Designing Equity-Based Pay

Brian J. Hall

NBER Working Paper No. 9887

July 2003

JEL No. J0, J3, L0, L2

\section{$\underline{\text { ABSTRACT }}$}

During the past two decades, there has been a dramatic increase in equity-based pay for executives. This paper analyzes why the primary goal of the equity-pay explosion--creating long-run ownership incentives for top executives--has often been difficult to achieve in practice. More generally, I describe six challenges in the design of equity-based pay plans and discuss potential solutions. The six challenges involve:

1. mismatched time horizons;

2. gaming;

3. the value-cost "wedge";

4. the leverage-fragility tradeoff;

5. aligning risk-taking incentives; and

6. avoiding excessive compensation.

The paper also discussed the merits of stock versus options and concludes that restricted stock is often a superior form of compensation.

Brian J. Hall

Harvard Business School

Baker Library 185

Boston, MA 02163

and NBER

bhall@hbs.edu 


\title{
SIX CHALLENGES IN DESIGNING EQUITY-BASED PAY
}

\author{
by Brian J. Hall, Harvard Business School*
}

There has been a dramatic change in both the level and composition of executive pay in the U.S. during the last two decades. Executive compensation has increased sharply, driven almost entirely by an explosion in stock option grants. What's more, the trend toward equitybased pay appears to be spreading to the rest of the developed world.

But what has equity-based pay really accomplished, and what can we expect in the future? Let's start with what can go right. Besides attracting and retaining a high-quality management team, well-designed stock and stock option packages can increase corporate productivity and value by better aligning top managers' interests with those of the shareholders. And despite all of the recent controversy, research shows that the increased use of stock options has greatly strengthened the link between executive pay and corporate performance during the last decade or two. In their much-cited 1990 study of U.S. companies in the 1970s and early 1980s, Michael Jensen and Kevin Murphy reported that for every \$1,000 change in a company's market value in a given year, the average CEO's total compensation for that year changed by only about three dollars. In a study almost a decade later, Jeff Liebman and I found that by the end of the 1990s, the pay-to-performance link for U.S. CEOs had jumped almost tenfold since 1980due almost entirely to the proliferation of stock options during the $1990 \mathrm{~s} .{ }^{1}$

Yet this change in no way suggests that the stock option revolution has been all to the good. Indeed, the current method of rewarding executives has significant flaws, as demonstrated by recent events when top executives of many companies cashed out significant portions of their options during the end of the bull market of the 1990s, a period when stock prices proved unsustainably high. And whether achieved by accident or design, the resulting transfer of wealth to selling managers from existing (and particularly buying) shareholders generated considerable skepticism about corporate governance in general and executive compensation in particular. At

\footnotetext{
* This article was prepared with the assistance of Research Associate Aaron M. G. Zimmerman. It draws heavily on material in Incentive Strategy II: Executive Compensation and Ownership Structure (HBS No. 902-134).

${ }^{1}$ See Michael C. Jensen and Kevin J. Murphy, "Performance Pay and Top Management Incentives," Journal of Political Economy, April 1990, pp. 225-265; Brian J. Hall and Jeffrey B. Liebman, "Are CEOs Really Paid Like Bureaucrats?" Quarterly Journal of Economics, August 1998, pp. 653-691; and Brian J. Hall, "What You Need to Know About Stock Options," Harvard Business Review, March-April 2000, pp. 121-129.
} 
the same time, companies whose stock prices have plummeted are now struggling with the dual problem of retaining employees with deeply underwater options and placating shareholders strongly opposed to repricing those options.

What has also become clear is that designing an effective equity-based compensation plan - one that motivates long-term value-maximizing behavior - is not a simple task. There are difficulties associated with time horizons, opportunistic selling, the gaming of accounting numbers and stock prices, risk-taking, fairness, and what I will call option "fragility." Moreover, as this article will make clear, most stock options are worth considerably less to the executives they are meant to motivate than to the shareholders of the companies that grant them. This "wedge" in value represents a significant cost to the firm's shareholders-one that could tilt the balance toward the use of restricted stock or cash-based compensation instead. Until recently, corporate decisions to grant options rather than restricted stock have clearly been influenced by a quirk of accounting - the fact that companies need not expense option grants on their income statements, whereas the cost of restricted stock, indexed options, and virtually all other executive compensation must flow through the $\mathrm{P} \& \mathrm{~L}$. But a growing sensitivity to the drawbacks of options (which will only be reinforced if the accounting treatment is changed) is likely to cause many companies to consider restricted stock and cash-based compensation as more cost-effective alternatives to options.

In this article, I discuss the major challenges in designing equity-based play plans that effectively link executive compensation to long-run shareholder value. Besides encouraging executives to balance long-term performance goals against the pressures to meet near-term earnings targets, corporate pay plans must also perform another difficult balancing actmaintaining a strong pay-for-performance link (including reduced rewards when stock prices fall) while at the same time retaining capable executives. There are dramatic differences in equitybased pay plans, and the way companies set up these plans can have powerful effects on both incentives and retention. But incentives can be a double-edged sword and must be carefully managed to prevent the loss of shareholder confidence and value.

\section{EXECUTIVE COMPENSATION: RECENT HISTORY AND TRENDS}

As late as 1984, fewer than half of the CEOs of publicly traded U.S. companies were granted any stock or stock options in a given year. With hindsight, it now seems clear that the resulting misalignment of incentives between managers and owners was a major contributor to the wave of U.S. corporate restructurings in the 1980s. Private equity firms like Kohlberg Kravis 
Roberts \& Co. (KKR) and Clayton Dubilier \& Rice bought up underperforming companies-or, in many cases, subsidiaries of large conglomerates - and achieved remarkable performance improvements by forcing managers to focus on profitability and shareholder value. The change in managers' motivation came from three main sources: meaningful equity ownership, high debt payments that provided a new discipline by leaving managers with little free cash flow, and more active monitoring by a board made up entirely of major equity investors. ${ }^{2}$

George Roberts, one of the founders of KKR, summed up the prevailing view of the importance of ownership incentives as follows:

Just as you are likely to take better care of a home you own than one you rent, managers and boards with a financial commitment to their business are virtually always more effective in creating both short- and long-term value... Companies perform better when all important parties - management, employees, and directors - have the incentive of ownership in the business. ${ }^{3}$

In virtually all of these transactions, the top managers became co-owners by purchasing stock with their own or borrowed money and through compensation in the form of stock and options. And the fact that the early buyout firms referred to their transactions as "management buyouts" (rather than "leveraged buyouts," as they later became known) reflected the conviction that in terms of motivating executives to increase profitability and firm value, ownership structure and incentives were more important than the way the transactions were financed.

The success of the management buyouts in raising productivity and shareholder value did not go unnoticed by the shareholders of public companies. ${ }^{4}$ In the early $1990 \mathrm{~s}$, after the leveraged restructuring movement had been shut down by a combination of market and regulatory forces, institutional investors began to use their power as owners to push managers to increase returns to shareholders. This development, along with the sharp rise of venture-backed companies, led to

\footnotetext{
2 See Steven Kaplan, "The Evolution of U.S. Corporate Governance: We Are All Henry Kravis Now," Journal of Private Equity, 1997, pp. 7-14; Bengt Holmstom and Steven Kaplan, "Corporate Governance and Takeovers in the U.S.: Making Sense of the '80s and '90s," Journal of Economic Perspectives, Spring 2001, pp. 121-144; and Bengt Holmstrom and Steven Kaplan, "The State of U.S. Corporate Governance: What's Right and What's Wrong?," Journal of Applied Corporate Finance, Spring 2003.

${ }^{3}$ George R. Roberts, "Corporate Governance and the Power of Ownership," The Corporate Board, September/October 1998.

${ }^{4}$ For evidence that LBOs raised productivity and shareholder value, see, for example, Steven Kaplan, "The Effects of Management Buyouts on Operations and Value," Journal of Financial Economics (1989), Vol. 25, pp. 217-254; and Krishna G. Palepu, "Consequences of Leveraged Buyouts," Journal of Financial Economics, Vol. 27 (1990), pp. 247-262.
} 
an enormous increase in the proportion of stock and (especially) stock options in top management compensation packages.

Figure 1 The Level and Composition of Median CEO Pay in the U.S. from 1980 to 2001 (in 2001 dollars)

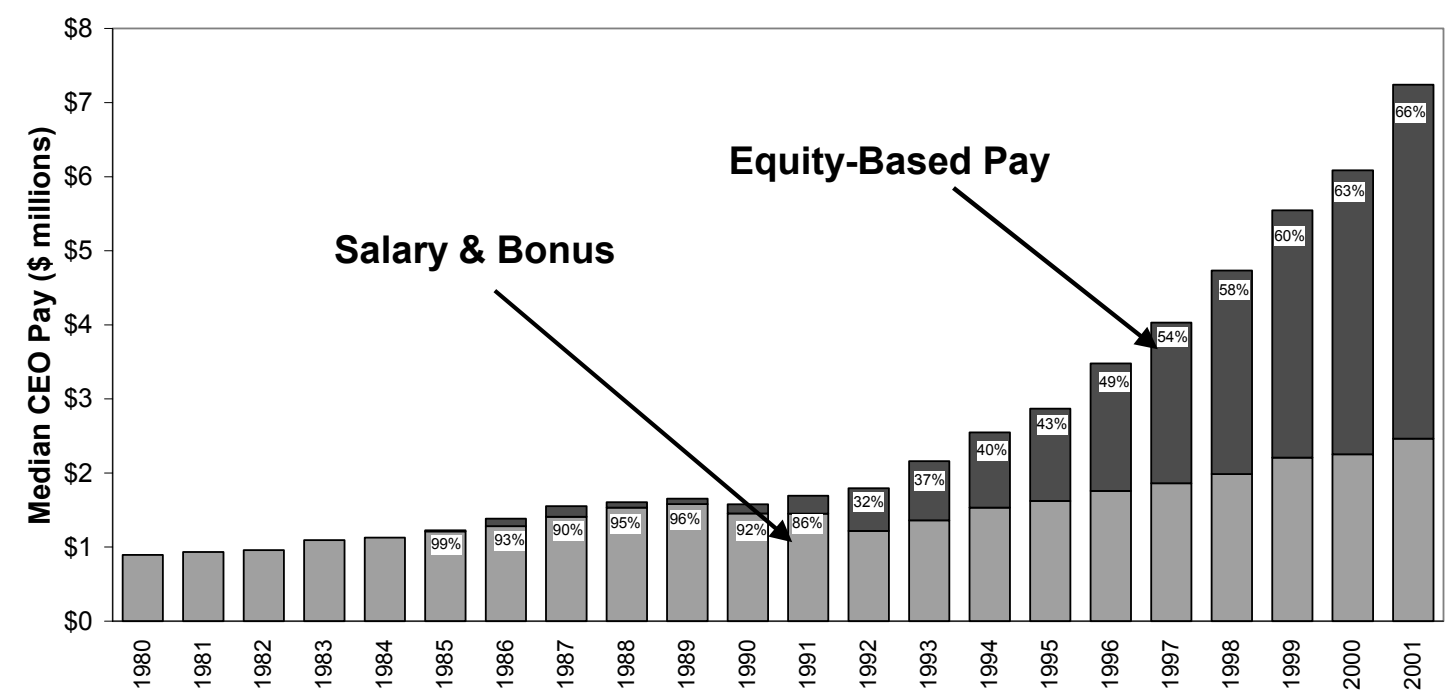

Source: ExecuComp and data derived and spliced together from Hall-Liebman (1998) and Hall-Murphy (2002a). The data from 1992 to 2000 are from S\&P500 Industrial companies while the data from the earlier years are from a sample of Forbes 500 companies.

Figure 1 shows the level and composition of top executive pay over the period 19802001. By 2001, equity-based pay constituted about two-thirds of the median annual total pay of U.S. top executives, up from zero as late as 1984 . What's more, by the end of the 1990s, annual changes in the value of executives' portfolios of company stock and options were swamping annual changes in cash pay. In fact, studies estimated that, in a year of "normal" stock price volatility, changes in the value of executive stock and options were as much as 50 times the annual change in cash pay. ${ }^{5}$

Perhaps even more striking is the sharp increase in the level of top executive pay during the period. The median CEO pay package rose from about \$1 million in 1980 to over $\$ 7$ million in 2001 (measured in 2001 dollars). Thus, while the pay of the average rank-and-file worker

${ }^{5}$ See Brian J. Hall and Jeffrey B. Liebman, “Are CEOs Really Paid Like Bureaucrats?," Quarterly Journal of Economics, August 1998, pp. 653-691; and surveys by Kevin J. Murphy, "Executive Compensation," in Handbook of Labor Economics, Vol. 3 (1999), edited by O. Ashenfelter and D. Card; Robert M. Bushman and Abbie J. Smith, "Financial Accounting Information and Corporate Governance," University of Chicago Working Paper, April 2001; and John E. Core, Wayne Guay, and David F. Larcker, "Executive Equity Compensation and Incentives: A Survey," Working Paper, University of Pennsylvania, January 2002. 
increased (in inflation-adjusted terms) by about $15 \%$ over the past 20 years, CEO pay increased by nearly $600 \%$. The only major groups with commensurate or larger percentage pay increases during this period were "superstar" actors and professional athletes. ${ }^{6}$

And U.S. trends in executive pay appear to be spreading internationally. Table 1 shows changes in the composition of pay between 1996 and 2001 in 23 of the wealthiest countries (averaged by continent). In each of the groups, the share of equity-based pay (as a percentage of total pay) increased by 12 percentage points or more, and such increases were all within range of the 19-percentage-point increase in the U.S. (The main difference, of course, is that the proportion of equity-based pay in the U.S. in 1996 was already much higher than in other countries.) And the same pattern emerges in the share of total "at-risk" pay - that is, cash bonus plus equity-based pay. The percentage-point increase in U.S. at-risk pay is comparable to that in the other countries, although the U.S. share again begins and ends at a much higher level.

Table 1 Changes in Executive Pay Composition: International Comparisons

\begin{tabular}{lccc|ccc}
\hline & \multicolumn{3}{c|}{ Share of Equity-based Pay } & \multicolumn{3}{c}{ Share of At-Risk Pay } \\
& $\mathbf{1 9 9 6}$ & $\mathbf{2 0 0 1}$ & Change & 1996 & $\mathbf{2 0 0 1}$ & Change \\
\hline Europe (9) & $6 \%$ & $18 \%$ & $\mathbf{1 2 \%}$ & $24 \%$ & $37 \%$ & $\mathbf{1 3 \%}$ \\
Asia (6) & $6 \%$ & $24 \%$ & $\mathbf{1 8 \%}$ & $23 \%$ & $39 \%$ & $\mathbf{1 6 \%}$ \\
Latin America (4) & $0 \%$ & $21 \%$ & $\mathbf{2 1 \%}$ & $26 \%$ & $45 \%$ & $\mathbf{1 9 \%}$ \\
Commonwealth (3) & $8 \%$ & $20 \%$ & $\mathbf{1 2 \%}$ & $\mathbf{2 7 \%}$ & $46 \%$ & $\mathbf{1 9 \%}$ \\
U.S. (1) & $32 \%$ & $51 \%$ & $\mathbf{1 9 \%}$ & $51 \%$ & $68 \%$ & $\mathbf{1 7 \%}$ \\
\hline $\begin{array}{l}\text { Average (of 23 } \\
\text { countries) }\end{array}$ & $6 \%$ & $22 \%$ & $\mathbf{1 6 \%}$ & $26 \%$ & $42 \%$ & $\mathbf{1 6 \%}$ \\
\hline
\end{tabular}

Source: Author's calculations using data supplied by Towers Perrin. The data are for industrial companies with $\$ 500$ million in sales. The commonwealth countries are Australia, New Zealand, and Canada. The share of equity-based pay includes the present value of "long-term incentives," which primarily consist of stock, options and other equity-like pay. The number in parentheses indicates the number of countries included.

Equity-based pay has also increasingly become part of the compensation package for lower-level managers and workers. Indeed, a 1999 study by William M. Mercer found that about $40 \%$ of all large U.S. companies granted stock options to at least half of their employees, more than doubling from the early 1990s. And this trend is particularly prevalent in the high-tech sector. For example, at Akamai, an e-business infrastructure services provider, the heavy use of

\footnotetext{
${ }^{6}$ Brian J. Hall and Jeffrey B. Liebman, "The Taxation of Executive Compensation," in Tax Policy and the Economy, NBER volume edited by J. Poterba, MIT Press, Vol. 14, 2000.
} 
stock options is said to reflect management's and the board's belief that "all employees should be owners and have equity." In the words of Akamai president Paul Sagan, "Equity was a way of doing something that was psychological as well as financial — it was motivational to people and made them part-owners. The sense was that we were working to build a new endeavor. It was a big idea, but not without some risk - so there ought to be some big upside reward that comes with that risk." 8

It is hard to estimate precisely the degree to which equity-based pay motivates managers and employees to increase shareholder value since cause and effect are difficult to disentangle. Nevertheless, there is now a considerable body of empirical evidence that suggests that equity holdings motivate executives to raise profitability and increase shareholder value. For example, several recent studies have found that increases in stock-based pay are followed by improvements in both accounting and stock price performance. ${ }^{9}$

\section{CHALLENGES IN EQUITY-BASED PAY DESIGN}

Incentives, however, can cut both ways. If not designed with care, equity-based pay plans can end up motivating behavior that destroys value. There are six fundamental challenges in designing equity-based pay plans that correctly align managerial (and employee) incentives with the pursuit of shareholder value:

1. mismatched time horizons;

2. gaming;

3. the value-cost "wedge";

4. the leverage-fragility tradeoff;

5. aligning risk-taking incentives; and

\footnotetext{
${ }^{7}$ Brian J. Hall, Houston Lane, and Jonathan P. Lim, “Akamai’s Underwater Options (A),” HBS Case No. 902-069, page 5 .

${ }^{8}$ Ibid.

${ }^{9}$ See John E. Core and David F. Larcker, "Performance Consequences of Mandatory Increases in Executive Stock Ownership," Journal of Financial Economics, Vol. 63 (2002), pp. 315-40. See also Hamid Mehran, "Executive Compensation Structure, Ownership, and Firm Performance," Journal of Financial Economics, Vol. 38 (1995), pp. 163-184; John J. McConnell and Henri Servaes, “Additional Evidence on Equity Ownership and Corporate Value," Journal of Financial Economics, Vol. 27 (1990), pp. 595-618; and Melissa Frye, "Equity-Based Compensation for Employees: Firm Performance and Determinants," Working Paper, University of Central Florida, 2001, for similar evidence. Other studies describe and analyze the reasons why such evidence is hard to interpret; see, for example, Murphy (1999), Bushman and Smith (2001), and Core, Guay, and Larcker (2002), all cited in footnote 3.
} 
6. avoiding excessive compensation.

Understanding these six challenges provides important insight into the design of equity-based pay.

\section{Challenge 1: Mismatched Time Horizons}

Well-designed equity plans motivate sustainable, or long-run, value creation. One advantage of stock-based pay in this regard is that while accounting profits measure the past, stock prices reflect expectations about the future; they represent the market's best forecast of how current actions will affect future profitability. And investors, who can lose a lot of money by being wrong, have strong incentives to scrutinize executive decisions closely. Viewed in this light, equity incentives are the best protection against short-term thinking.

But even so, equity-based pay is often criticized as encouraging executives to manage short-term earnings to appease Wall Street instead of managing for long-run value creation. And given the market's occasional bouts of excessive optimism, executives may be tempted to fool the market by figuring out ways to temporarily prop up their stock prices and then cash out their equity holdings. Under pressure to boost the stock price, for example, managers may cut R\&D or take other actions that increase short-term earnings at the expense of (appropriately discounted) long-run cash flow. Such "short termism" is likely to be especially tempting for managers nearing retirement or whose jobs are on the line because of weak performance.

Solving, or at least limiting, the problem of short termism requires lengthening vesting periods and strengthening executive "ownership requirements." While many stock and option plans have vesting periods of four or five years, others have considerably shorter vesting periods. Al Dunlap of Sunbeam had stock and options that vested over his first two years as CEO, and when Sunbeam's stock price surged, the contract was renegotiated to reduce the vesting period. ${ }^{10}$ Virtually all executive contracts trigger "accelerated" vesting when an executive retires, which is likely to limit the value-creation horizons of executives approaching retirement.

Why are vesting periods so short? Executives prefer short vesting because it makes their compensation less risky, and they are often able to get their boards to go along. But boards should ask why an executive is "demanding" a short vesting period. What does that say about the executive's future plans and motivations? Or about the executive's confidence that he or she can successfully lead the company over the long haul?

\footnotetext{
10 See Brian J. Hall, Rakesh Khurana, and Carleen Madigan, “Al Dunlap at Sunbeam,” HBS Case No. 899-
} $218,1999$. 
Although vesting periods of five years or longer - and that extend beyond an executive's tenure with the firm - represent a significant step in the right direction, longer vesting alone is not a perfect solution to the horizon problem. Requiring executives to build up and hold company stock over a period of time - by purchasing the stock or by holding on to some portion of the stock after an option exercise - is also important for ensuring that executives have long horizons. Indeed, nearly half of large companies have formal "ownership guidelines" that require their top executives to acquire (over some number of years) company stock holdings with a value equal to some multiple (four to seven is the typical range) of annual salary. ${ }^{11}$ Long vesting of current equity compensation, combined with requirements that executives continue to amass and hold significant equity stakes, can go a long way toward lengthening managerial value-creation horizons.

\section{Challenge 2: Gaming}

A close cousin of the horizon problem is the "gaming" problem. Equity-based pay, combined with the intense pressure to meet Wall Street's expectations, can push some executives to use accounting tricks or outright falsification of information to artificially boost the stock price. ${ }_{12}$ Unfortunately, high-powered equity-based pay-particularly when combined with very short or no vesting restrictions - can encourage actions that are unethical and wasteful at best, and massively value-destroying and fraudulent at worst. ${ }^{13}$ The incentives to "game the system" and engage in questionable or illegal behavior are especially strong for managers in "overpriced"

\footnotetext{
11 Approximately 45\%, according to Frederic W. Cook \& Co.'s study of the 250 largest U.S. companies according to market capitalization, "2002 Top 250."

${ }^{12}$ Some of the recent corporate scandals appear to have been associated with sharp increases in equitybased pay without a strengthening of checks and balances. In the case of Enron, for example, these internal controls and boundary systems seem to have been quite weak. See Malcolm Salter, "Innovation Corrupted: The Rise and Fall of Enron," HBS Case No. 903-032, 2003.

13 According to one study, option grants are followed by abnormal company returns, suggesting that executives are using their inside information about company performance to affect the timing of option grants (see David Yermack, "Good Timing: CEO Stock Option Awards and Company News Announcements," Journal of Finance, June 1997, pp. 449-476). But another study (Jennifer N. Carpenter and Barbara Remmers, "Executive Stock Option Exercises and Inside Information," Journal of Business, Vol. 74 (2001), pp. 513-534) found no evidence that abnormal negative stock price performance follows executive stock sales, implying either that this type of gaming is not widespread or that executives trying to time sales are simply not very good at it. Neither study rules out the possibility that some executives have successfully gamed the system by timing the sales of their company stock.
} 
companies, where the pressure to meet the unrealistic expectations of Wall Street can be very great. ${ }^{14}$

More generally, the temptation to game the system increases with the potential rewards (or lack of punishments) associated with gaming. Thus, managing the gaming problem requires boards and companies to pay close attention to these temptations and, especially, to strengthen internal controls. This means devoting resources to building and reinforcing corporate systems designed to monitor risky behavior and to detect and deter gaming. It may also call for improvements in the way the company communicates to its employees (through corporate codes of ethics, for example) the kinds of actions and behaviors that are clearly off-limits. ${ }^{15}$

One way to interpret the recent corporate scandals is that the massive increase in equitybased pay during the previous decade or two created a corresponding increase in the temptations to game without the appropriate increase in internal controls and other checks against cheating. In some respects, boards became less focused on measuring and evaluating executive performance since so much of executive compensation was tied to stock price performance and so little to other measures of executive performance. Put another way, boards had "outsourced" performance evaluation to the stock market. But while the market is a powerful and useful measure of executive performance, the heavy reliance on equity-based pay calls for perhaps more, not less, rigorous evaluation of CEO actions and performance.

\section{Challenge 3: The Value-Cost "Wedge"}

Mismatched time horizons and gaming are two fairly well-known problems that arise with equity-based pay. But an even more fundamental issue is the potentially significant disparity between the real cost of an equity grant and the value of that grant to the executive or employee. For the company, the market value of an equity grant represents the economic or "opportunity" cost of the equity — the amount the company could receive if the equity were sold to an outside investor rather than given to an executive or employee. ${ }^{16}$ But because executives

\footnotetext{
14 Joseph Fuller and Michael C. Jensen, "Just Say No to Wall Street: Putting a Stop to the Earnings Game," Journal of Applied Corporate Finance, Winter 2002, pp. 41-46.

15 See Robert Simons, Performance Measurement and Control Systems for Implementing Strategy (Upper Saddle River, NJ: Prentice Hall, 2002) for a more detailed analysis of internal controls and boundary systems.

${ }^{16}$ But if the company's cost of equity pay is thus reasonably approximated by its market value, that value must be adjusted for early exercise and expected forfeiture, both of which lower the cost on average. Furthermore, the cost to shareholders is independent of whether companies pay for the options by dilution (issuing new shares to pay option holders) or through share repurchases (which creates a cash cost). See Brian J. Hall, “Exercise on Employee Stock Option Dilution,” HBS Case No. 902-162, 2002.
} 
and employees are risk-averse and tend to hold personal asset portfolios that are "undiversified," they generally value equity-based pay at less than its market value (as estimated using standard models such as Black-Scholes). That is, because executives are forced (by vesting requirements, insider sales restrictions, or board pressure) to hold more company equity—and usually much more - than is desirable from a portfolio-diversification standpoint, they discount the value of their company equity holdings. ${ }^{17}$

As a general rule, then, the value to the executive of equity pay is generally lower than its cost to the company's shareholders. The value-to-cost $(\mathrm{V} / \mathrm{C})$ ratio depends on a number of factors, ${ }^{18}$ including:

1. the degree of diversification in the executive's holdings (greater diversification increases $\mathrm{V} / \mathrm{C}$ );

2. the risk aversion of the executive (greater risk aversion lowers $\mathrm{V} / \mathrm{C}$ );

3. the volatility of the stock (higher volatility lowers $\mathrm{V} / \mathrm{C}$ );

4. the vesting period of the equity (longer vesting lowers $\mathrm{V} / \mathrm{C}$ ); and,

5. in the case of stock options, the extent to which the options are in-the-money (the more in-the-money, the higher is the $\mathrm{V} / \mathrm{C}$ ).

In the case of stock grants, the $\mathrm{V} / \mathrm{C}$ discount is fairly modest, generally on the order of $15 \%$ (or a 0.85 ratio) for an average-volatility stock. But for standard at-the-money stock option grants, there is often a significant gap between value and cost, with $\mathrm{V} / \mathrm{C}$ ratios ranging in most cases from 0.8 to as low as 0.4 . This suggests that option grants must be discounted (relative to their Black-Scholes value and assuming the options are not forfeited) by $20 \%$ to $60 \%$-with $30 \%$ to $40 \%$ being "typical" - in order to determine the executive value of an option. And that $30 \%$ to $40 \%$ represents a "deadweight loss" to the company's shareholders - a discount that, along with the market value of the option grant itself, must be justified by performance improvements stemming from the options-linked strengthening of retention and ownership incentives.

${ }^{17}$ See Brian J. Hall and Kevin J. Murphy, "Optimal Exercise Prices for Executive Stock Options," American Economic Review, May 2000, pp. 209-215, and "Stock Options for Undiversified Executives," Journal of Accounting and Economics, Vol. 33 (2002); also see Richard A. Lambert, David F. Larcker, and Robert E. Verrecchia, "Portfolio Considerations in Valuing Executive Compensation, Journal of Accounting Research, Vol. 29 (1991), pp. 129-150, and Lisa K. Meulbroek, "The Efficiency of Equitylinked Compensation: Understanding the Full Cost of Awarding Executive Stock Options," Financial Management, Vol. 30 (2001), pp. 5-45, for a more detailed analysis.

${ }^{18}$ See Hall and Murphy (2002), cited earlier 
In sum, the $\mathrm{V} / \mathrm{C}$ wedge is a significant part of the price that companies must pay in order to generate the benefits of equity-based pay. And, as I discuss later in more detail, this inefficiency could cause many companies to shift from option awards to restricted stock, or perhaps to shift some compensation away from equity and towards cash.

\section{Challenge 4: The Leverage-Fragility Tradeoff}

Partly offsetting the value-cost inefficiency of options is the fact that they are a "leveraged" incentive device. That is, companies can grant employees more stock options than shares for the same cost to the company, since each option has a lower per-share cost than a share of stock. As a result, for a given increase in the stock price, the upside gain from a given (market) value of options is generally higher than that of stock. .

Table 2 shows how the value of stock or options changes with the stock price. The entries in the table assume that one employee receives a share of stock worth $\$ 100$ and another receives two at-the-money options, also worth $\$ 100$. The entries in the left half of the table show how the market value of the stock and options (based on Black-Scholes) changes when the stock price changes. Increases in the stock price lead to exactly proportionate increases in the value of the stock award but proportionately greater increases in By contrast, the value of the options package increases more quickly than the stock package as the stock price increases. For example, a $50 \%$ increase in the stock price (from $\$ 100$ to $\$ 150$ ) results in a $50 \%$ increase in the value of the stock award but an $83 \%$ increase in the options package.

This analysis, however, fails to take into account the value-cost wedge-which, again, stems from the tendency of risk-averse and undiversified employees and executives to value options (and stock) at less than their market values. The risk-adjusted executive values of stock and options are shown in the middle column of Table 2, and their "normalized" (to 1) values are shown in the right right-hand columns to show percentage changes in values.

Accounting for risk aversion increases the difference between option and stock values. While the value of risk-adjusted stock still moves roughly in proportion with the stock price, the value of stock options increases even more sharply (in percentage terms) when the stock price increases. Option values rise sharply in percentage terms as options move into the money. Options have great upside potential. Options are highly leveraged, and this leverage effect increases when the value-to-cost $(\mathrm{V} / \mathrm{C})$ ratio is taken into account.

\footnotetext{
${ }^{20}$ Brian J. Hall and Thomas A. Knox, "Managing Option Fragility," NBER Working Paper No. w9059, July 2002.
} 
Option fragility. But the leverage of options operates in both directions. As shown in the table, the value of options also falls sharply in response to stock price decreases. For example, a $50 \%$ fall in the stock price (from $\$ 100$ to $\$ 50$ ) lowers the value of the options by $69 \%$ (from $\$ 100$ to $\$ 31$ ) - and by $82 \%$ (from $\$ 65$ to $\$ 12$ ) when executive risk aversion is taken into account. This helps explain why risk-averse individuals perceive far-underwater options as being almost worthless. While this may be perhaps an attractive feature in terms of "punishing" executives (and employees) for decreases in the stock price, it also makes option incentives fragile. That is, as options move farther out of the money, they tend to lose their power both to motivate and to retain executives.

Table 2 Comparing the Upside Potential and Downside Risk of Stock and Options

\begin{tabular}{c|cc|cc|cc}
\hline & \multicolumn{2}{|c|}{ Market Value } & \multicolumn{2}{c|}{$\begin{array}{c}\text { Executive (Employee) } \\
\text { Value }\end{array}$} & \multicolumn{2}{c}{$\begin{array}{c}\text { Normalized Executive } \\
\text { Value }\end{array}$} \\
\hline Stock Price & Stock & Options & Stock & Options & Stock & Options \\
\hline$\$ \mathbf{0}$ & $\$ 0$ & $\$ 0$ & $\$ 0$ & $\$ 0$ & 0 & 0 \\
$\mathbf{2 5}$ & 25 & 8 & 21 & 1 & 0.25 & 0.02 \\
$\mathbf{5 0}$ & 50 & 31 & 43 & 12 & 0.50 & 0.14 \\
$\mathbf{7 5}$ & 75 & 63 & 64 & 35 & 0.75 & 0.54 \\
$\mathbf{1 0 0}$ & $\mathbf{1 0 0}$ & $\mathbf{1 0 0}$ & $\mathbf{8 5}$ & $\mathbf{6 5}$ & $\mathbf{1 . 0 0}$ & $\mathbf{1 . 0 0}$ \\
$\mathbf{1 2 5}$ & 125 & 140 & 105 & 98 & 1.24 & 1.50 \\
$\mathbf{1 5 0}$ & 150 & 183 & 126 & 140 & 1.48 & 2.15 \\
\hline
\end{tabular}

Source: Executive value calculations are risk-adjusted measures (certainty equivalents), taken from Hall and Knox (2002) and Hall and Murphy (2002). The right-hand columns show normalizations - equal to 1.00 when the options are at-the-money to highlight percent changes in option values as they move into or out of the money. Market value calculations are based on Black-Scholes assuming $50 \%$ volatility, five-year maturity, no dividend, and a $6 \%$ risk-free interest rate.

Moreover, the probability of options falling under water is significant. Even at the height of the bull market in 1999, about one-third of all options held by U.S. executives in publicly traded companies were underwater. ${ }^{20}$ In 2001, this number averaged over 50\%. Although options are more fragile in bear markets, they are also fragile incentive instruments in bull markets. ${ }^{21}$

Managing Leverage and Fragility. Designing option packages that properly balance the tradeoff between leverage and fragility is a difficult task. There are three basic types of

${ }^{21}$ Ibid. 
option plans, each of which varies in terms of leverage and fragility. ${ }^{22}$ Large, upfront grants (also known as "megagrants"), which fix the exercise price and number of options at the beginning, are highly leveraged and have the desirable feature (especially from the perspective of the recipient) of producing a very high payoff when the stock price increases. Megagrants thus provide powerful incentives initially, but these incentives will erode if the stock price falls substantially. And if the drop in stock price is due mainly to factors beyond management's control, the result may well be the loss of good managers.

Fixed-value plans, which pay a certain pre-determined Black-Scholes value each year, have the opposite problem. They are not as highly leveraged on the upside; in fact, if the stock price increases in a given year, the recipient receives fewer options and at higher exercise prices at the beginning of the next. But such plans are much more robust in the event of stock price declines. If the stock price drops in a given year, the executive actually receives a larger number of options (at the now lower exercise price) in order to hold constant the value of the annual grant.

But if fixed-value plans can help retain executives who might be demoralized by a drop in the company's stock price, the fact that such a policy can end up rewarding poor performance (by granting more stock options after down years) means that it can also work to undermine incentives. A partial solution to this incentive problem is provided by multi-year plans that pay a fixed number of at-the-money options each year. Such fixed-number plans represent a compromise between megagrants and fixed-value plans. They provide smaller rewards for exceptional performance than megagrants but stronger incentives (and hence retention power) in the event of stock price declines. At the same time, they avoid the distortion of incentives in fixed-value plans by increasing the value of option grants following good years and decreasing their value after down years.

In designing equity-based pay packages, then, companies must carefully weigh the incentive benefits of leverage against the retention costs of fragility. ${ }^{23}$ The challenge in designing multi-year option plans is to create sufficient upside potential for incentive alignment purposes while at the same time preserving the company's ability to retain and motivate executives if the stock price falls sharply. After large price declines, many companies, in

\footnotetext{
22 Brian J. Hall, "What You Need to Know About Stock Options," Harvard Business Review, March-April 2000, pp. 121-129, and "The Design of Multi-year Stock Option Plans," Journal of Applied Corporate Finance, Vol. 12 No. 2 (Summer 1999), pp. 97-106.

${ }^{23}$ For more detailed analysis of the relative merits of each of these types of plans, see Hall (2000), cited earlier.
} 
practice, grant "extra" options the following year-a form of back-door repricing. ${ }^{24}$ But if this response makes sense when price declines are caused by factors that are clearly beyond the executives' control, it is likely to provoke unrest among stockholders when poor management and not poor market conditions is to blame.

The Case for Indexed Options. Many academics, and some in the press, argue that indexed options - where the exercise price is tied to some market or industry index — create the possibility of a tighter link between pay and performance without jeopardizing executive retention. With indexed options, executives are rewarded (or punished) according to their success in outperforming their competitors or the broad market. Yet despite what appear to be significant advantages to indexed options, they are virtually nonexistent. A survey of one thousand companies found that only one company had an indexed option plan. ${ }^{27}$ Of course, indexed options are somewhat complex and can introduce difficult design problems. For example, what index should be used? Should the index be "beta" adjusted? Do we always want to remove industry or market changes? ${ }^{28}$ Will executives and employees understand them?

But the main obstacle to indexed options is probably their unfavorable accounting treatment - the cost of such options must be expensed on corporate income statements. If the same treatment is eventually extended to standard at-the-money options, we are likely to see more interest in the design of indexed equity pay..$^{29}$

\footnotetext{
${ }^{24}$ Hall and Knox (2002)

27 Note that the fact that indexed options are rarely used even by companies with large owners, who have strong incentives to design equity-pay instruments well, is a challenge to the view that any type of indexed options are a good idea.

${ }^{28}$ For evidence and analysis regarding indexed options, see Lisa K. Meulbroek, "Restoring the Link Between Pay and Performance: Evaluating the Costs of Relative-Performance-Based (Indexed) Options," HBS Working Paper 02-021, 2001, and "Designing an Option Plan that Rewards Relative Performance: Indexed Options Revisited," HBS Working Paper 02-022, September 2001; see also Shane A. Johnson and Yisong S. Tian, “Indexed Executive Stock Options," Journal of Financial Economics, Vol. 57 (2000).

${ }^{29}$ WebScale in "Sara's Options" (Brian J. Hall, Peter Tufano, and Joshua Musher, HBS Case No. 201-005, 2001) is a rare example.
} 


\section{Challenge 5: Aligning Risk-Taking Incentives}

One of the most commonly alleged benefits of options is that they help overcome managers' natural aversion to risk. Although it is hard to know the optimal level of risk-taking for a given company, there are good reasons to believe that,, without the risk-taking incentives provided by equity-based pay, executives would be overly conservative with the corporate assets they manage. There are two main reasons for this. First, it is not irrational for executives to want to avoid risky bets that may jeopardize their positions. Since they are much more likely to be fired for poor company performance, they may be wary of taking bets - even bets with high expected payoffs - that have a significant chance of failure. Second, risk-averse executives with a disproportionate amount of financial and human capital invested in one firm will rationally tend to take fewer risks (harking back to the value-cost wedge). Options promote more risk-taking because increases in the volatility of a company's stock price actually increase the value of its options (while leaving stock prices unaffected). Options can thus add value by encouraging managers to move the firm closer to its optimal level of risk. ${ }^{30}$

But standard options do not necessarily induce more risk-taking because there are two opposing forces at work. Managers with lots of at-the-money (or in-the-money) options can become overly cautious, unwilling to jeopardize a large anticipated payoff that will accrue even if the stock price increases at just the T-bill rate. On the other hand, options increase in expected value in response to higher volatility and risk. Thus, although the risk aversion of executives makes them want to reduce risk following the option grant, the higher expected payoff encourages more risk-taking - and the net effect of these two factors is uncertain.

Although the effect of executive risk aversion is hard to measure, the relationship between greater risk-taking and higher payoffs can be quantified. Table 3 shows how the value

\footnotetext{
30 Options can also encourage overly risky behavior, either because options more than offset natural biases against risk-taking or because these biases are inconsequential, especially if the options are way out of the money. Perhaps the most direct evidence we have on this issue relates to the behavior of S\&L managers and owners. When the S\&Ls became insolvent, or nearly so, in the 1980s, the owners/managers of these institutions were confronted with option-like payoffs (and federal deposit insurance enabled them to "borrow" from depositors without paying for their risk-taking behavior). They would become very wealthy if the risky loans paid off, and would lose little or nothing if the bets did not pay off. The result was the S\&L crisis, which necessitated a taxpayer-financed bailout on the order of hundreds of millions of dollars. For details about risk-taking incentives and behavior in banking, see Benjamin C. Esty, "Organizational Form and Risk Taking in the Savings and Loan Industry," Journal of Financial Economics, April 1997, pp. 25-56, and "The Impact of Contingent Liability on Commercial Bank Risk Taking," Journal of Financial Economics, February 1998, pp. 189-218.
} 
of at-the-money options (where both the strike price and the stock price are equal to \$129) changes when volatility increases by $10 \%$ (or five percentage points), from $50 \%$ to $55 \%$. The option value increases by about $6 \%$, from $\$ 65.83$ to $\$ 69.86$. This represents a "risk-taking elasticity" oof 0.6 - that is, a $10 \%$ increase in volatility causes a $6 \%$ increase in option value.

Table 3 Incentives to Take Risks: How Option Value Changes as Volatility Changes

\begin{tabular}{llll}
\hline & At the Money & In the Money & Out of the Money \\
\hline $\begin{array}{l}\text { Option Value } \\
\text { - At 50\% volatility }\end{array}$ & $\$ 65.83$ & $\$ 180.67$ & $\$ 20.52$ \\
- At 55\% volatility & $\$ 69.86$ & $\$ 184.78$ & $\$ 23.32$ \\
Percent increase in option value & $6 \%$ & $2 \%$ & $14 \%$ \\
Risk-taking elasticity & 0.6 & 0.2 & 1.4 \\
\hline
\end{tabular}

Notes: All options have a five-year duration; dividends are assumed to be zero and the risk-free rate is $6.3 \%$. For at-the-money options, the stock price is $\$ 129$ and the exercise price is $\$ 129$. For in-the-money options, the stock price is $\$ 260$ and the exercise price is $\$ 129$. For out-of-the money options, the stock price is $\$ 65$ and the exercise price is $\$ 129$. Risk-taking elasticity is the percentage increase in option value divided by the percentage increase in volatility.

Note that the risk-taking elasticity is much smaller when the options are substantially in the money. For example, if the stock price is twice the strike price, the elasticity is only 0.2 . Inthe-money options thus create risk-taking incentives that are not too dissimilar from ordinary stock. Conversely, options that are substantially out of the money-in the example in the table, the stock price is half the strike price- have a risk elasticity of 1.4 , or more than twice the risk elasticity of the at-the-money options.

Out-of-the-money options, then, are quite responsive to changes in volatility. And it is not hard to see why: as options fall farther out of the money, the only way to produce a positive payoff is to pursue riskier investments that widen the tails of the distribution of possible outcomes. Risk-taking incentives are thus strongest for out-of-the-money options and weakest for in-the-money options (and weaker still for stock). ${ }^{31}$ in fact, standard (at-the-money) optionsespecially options that have moved significantly into the money-may actually cause executives to take fewer risks. ${ }^{32}$

\footnotetext{
${ }^{31}$ Note that the risk-taking incentives for options also increase as the option package (especially an underwater package) moves close to the maturity date. That is, the "end game" for underwater options can be particularly destructive.

${ }^{32}$ For evidence that options do increase risk-taking relative to stock, see Peter Tufano, "Who Manages Risk? An Empirical Examination of Risk Management Practices in the Gold Mining Industry," Journal of Finance 51, 1996. He finds evidence regarding risk management in the gold mining industry: Managers who hold options manage less gold price risk while managers who hold common stock manage more gold price risk. See also Richard A. Lambert, David F. Larcker, and Robert E. Verrecchia, "Portfolio Considerations in Valuing Executive Compensation, Journal of Accounting Research 29, Spring 1991, pp.
} 


\section{Challenge 6: Avoiding Excess}

Equity-based pay, especially option-based pay, generally consists of complex financial instruments, which can make valuation difficult. This presents two problems. First, to the extent that boards, managers, and employees fail to understand the value of options, and how option values change with stock price fluctuations, the usefulness of options as a compensation and incentive device is undermined. Second, the complexity of equity-based pay may lead to abuses and misallocations of value, since boards do not always understand how much value they are transferring to executives when they make option grants. And even if they do understand, boards that are overly friendly with top executives may use the complexity - and lack of transparencyof equity packages to make overly generous grants to their friends.

Apple CEO Steve Jobs was given an option grant with a Black-Scholes value in excess of \$500 million..$^{33}$ Likewise, Tyco’s CEO Dennis Kozlowski was granted nearly six million options - 5.1 million new options in Tyco, plus 800,000 options in the Tycom subsidiary—with a Black-Scholes value of $\$ 81$ million. ${ }^{34}$ It is hard to imagine that the size of these packages was necessary for either motivation or retention purposes. Did the board fully understand the value of the transfer they were making? Would such grants have been possible if the value of the (expected) transfer from shareholders to executives was less complex? Determining the optimal level of equity-based pay is a major challenge for boards.

\section{THE CASE FOR STOCK vs. OPTIONS}

Much of the preceding discussion of the challenges in equity-pay design has focused on options, since options have been the predominant form of equity-based pay for U.S. executives during the previous two decades. Yet if the key goal of equity-based pay is to create owners out of managers, why not use stock? After all, owners are stockholders, not option holders. Using

129-150, who fail to find evidence that options increase risk-taking behavior. Indeed, their evidence suggests (weakly) the opposite.

${ }^{33}$ This is based on the author's Black-Scholes calculation. See also Geoffrey Colvin, "The Great CEO Pay Heist," Fortune, June 25, 2001.

${ }^{34}$ Also, he received 800,000 shares of restricted stock on January 22, 2002, in a "retention agreement" detailed in the Tyco September 30, 2001 10-K filing. Unlike the millions of shares Kozlowski was granted in the past, 100,000 shares of this grant vest annually regardless of Tyco's performance. With the stock price closing at $\$ 47.55$ a share on the day they were granted, the 800,000 shares of restricted stock were worth \$38 million. Mark Maremont, “Tyco CEO’s Stock Options Yield \$99.9 Million Gain,” Wall Street Journal, January 30, 2001. 
the principles discussed so far, I now outline some of the significant advantages of restricted stock - stock that vests slowly over time-relative to options.

First, the incentives provided by stock ownership to improve performance and add value - and, in fact, to stay in the current job - are not so dramatically affected by changes in the stock price. As we saw earlier, the incentives created by options are fragile in the sense that both the incentive and retention effects of options diminish as the stock price falls. This fragility of option incentives is the reason why many companies have faced an underwater options crisis. Stock has the important advantage of not being able to fall underwater. Akamai, for example, addressed its underwater options problem by allowing its executives and employees to exchange their options for shares of stock (albeit fewer shares). That is, the company's management decided that the key advantage of options - its upside potential — was more than offset by its countervailing disadvantage - its fundamental fragility. Although less leveraged than options, restricted stock continues to provide reasonably strong ownership and retention incentives whether the stock price rises or falls.

Second, the value/cost ratio is generally higher for stock. As stated earlier, the value of equity-based pay to recipients is generally less than its true cost. Although the value/cost differential between stock and options varies with factors such as the diversification and risk aversion of the executive and the volatility of the stock, estimates suggest that the value-to-cost discount for stock is two to three times less than that of options under the most plausible assumptions. That is, while an executive holding a grant of restricted stock might value it at $80 \%$ to $90 \%$ of its cash value, he or she might value an (at-the-money) options grant at only $50 \%$ to $75 \%$ of its cash value, all other things constant. ${ }^{35}$ And critically important, because stock is more highly valued by executives and employees (per dollar of expected cost to shareholders), it can generate stronger and more cost-effective ownership incentives than options in a wide variety of cases. ${ }^{36}$ The relative merits of stock are particularly high when executives are fairly risk-averse and undiversified.

Finally, stock grants are much less complex to value and much more transparent- to stockholders, employees, and the press - than option grants. Deriving the value of an at-themoney option package is far trickier and involves use of a complex (and poorly understood) valuation model that produces what many practitioners call a "theoretical value." When Fortune magazine put Steve Jobs on the cover of a June 2001 issue and claimed that his options package

${ }^{35}$ See Hall and Murphy (2002), cited earlier.

${ }^{36}$ Ibid. 
was the largest-ever compensation package at $\$ 872$ million, Jobs countered that his option package was worth zero since the options were underwater. An argument in which the two sides differ by nearly a billion dollars suggests a fair degree of complexity. The package had a BlackScholes value of about $\$ 170$ million at the time the article was written. But the fact that the package could be said to be worth zero creates confusion about the issue, and confusion can lead to abuse.

It is noteworthy that most of the seemingly outrageous executive pay packages have involved options rather than stock, in part because boards better understand what they are giving away when they grant stock. To the extent that the complexity of option valuation contributes to excesses in pay, a change from option-based to stock-based pay should help curb such excesses.

\section{BUT IS EXECUTIVE PAY REALLY "EXCESSIVE"?}

With the surge in equity pay, newspapers and media reports have become saturated with stories about "executive greed" and "out-of-control pay." But despite the large increases in executive pay over the past two decades, and fairly convincing evidence of excesses in particular cases, it is hard to determine whether the overall level of executive pay is too high by looking at pay outcomes alone. The chief difficulty is that there is no obvious benchmark. What is "excessive"? Should executive pay be compared to employee pay? To the pay of investment bankers? The pay of European executives? What percentage of the upside (or downside) of shareholder value should executives receive?

Although it is hard to make strong statements about executive pay levels by looking at pay outcomes, it is possible to shed some light on this issue by looking at the pay-setting process. That is, it is hard to determine whether a pick-up baseball game was played fairly by looking only at the final score. But a close examination of the circumstances would allow such a determination - for example, did both teams have the same number of players, the same number of outs, and so forth.

One measure of "appropriate executive pay" is the level of compensation determined in competitive labor markets with a sound process overseen by an independent board. Let's analyze U.S. executive pay with regard to each of these three criteria.

Although there is clearly some degree of competition in executive labor markets, it varies widely by specific circumstances. Some executives compete with a large number of fairly similar candidates, while other executives — particularly at the CEO level—vie for positions among a 
pool with only a few candidates. In such situations, the CEO has great bargaining power and the executive labor market is not highly competitive.

A second clear contributor to the rise in CEO pay is an upward bias that is built into the executive pay-setting process. The compensation committees of boards make heavy use of "pay surveys" compiled by compensation consultants on executive pay at companies that are comparable (in terms of size, industry, and so on). But since most boards feel that their executives are "above average," they elect to pay in the upper half of the distribution-for example, at the $60^{\text {th }}$ or $75^{\text {th }}$ percentile. Although hard to prove conclusively, the proposition that the increased use of compensation surveys has contributed to the rise in executive pay is consistent with both the views of practitioners - including executives and compensation consultants themselves - and the findings of empirical studies. ${ }^{37}$

In a related vein, the use of surveys was encouraged by rule changes in 1993 that required companies to detail more fully the pay of their top executives in company proxy statements. One of the hopes of the new rules was that greater disclosure would slow the increase in executive pay, with the publicity about high pay working to curb abuses. But once executives began to see more clearly how much their peers were making, they wanted more-and boards granted more. Thus, although disclosure generally curbs excesses, in this case it may have had the opposite effect.

A third potential contributor to pay excesses is the lack of board independence. While some companies have strong and independent boards, other boards are filled with close associates of the CEO who are reluctant to rein in the CEO's pay, corrupting the pay process. ${ }^{38}$ Consistent with this, academic research suggests that companies with weaker governance structures award greater pay to top executives than do firms with stronger governance. ${ }^{39}$ Stronger boards can play an important role both in checking the power and influence of CEOs and in curbing excessive compensation.

\footnotetext{
${ }^{37}$ See John M. Bizjak, Michael L. Lemmon, and Lalitha Naveen, "Has the Use of Peer Groups Contributed to Higher Levels of Executive Compensation?," Working Paper, December 2000, and Jay W. Lorsch, “Compensating CEOs: A Process View," Harvard Business School Working Paper 99-013, 1998, for evidence and analysis.

${ }^{38}$ See Lucian A. Bebchuk, Jesse M. Fried, and David I. Walker, "Managerial Power and Rent Extraction in the Design of Executive Compensation," University of Chicago Law Review, Vol. 69 (3), pp. 751-846, for evidence and analysis that CEOs have too much power in the pay-setting process.

39 John E. Core, Robert W. Holthausen, and David F. Larcker, "Corporate Governance, CEO Compensation, and Firm Performance,” Journal of Financial Economics, Vol. 51 (1999), pp. 371-406.
} 
In sum, there are good reasons to believe that the executive pay process leads, at least in some cases, to excessive pay. The upward pressures on pay are particularly strong when the dominant form of executive pay is a complex and hard-to-value equity instrument like options.

\section{ACCOUNTING FOR OPTIONS}

Standard at-the-money option grants do not create an expense to the P\&L, either at the time of grant or at the time of exercise. By comparison, a restricted stock grant creates an immediate expense (as does the use of nonstandard options). Options are approximately 15 times more common than stock grants in the U.S. While there are many possible explanations for the dominance of options over stock, managers and other practitioners often claim that the accounting treatment of options is among the most important. Despite the fact that companies must disclose option compensation in mandatory footnotes, a surprisingly high percentage of managers believe that investors will punish the stock price if options are expensed, forcing their companies to cut back on their use.

The accounting treatment of options is currently at the center of a heated debate. Proponents of expensing options argue that options are a genuine cost to shareholders. As Warren Buffett has observed, "If options are not compensation, what are they? If compensation is not an expense, what is it? If expenses don't go on the P\&L, where do they go?" ${ }^{40}$ Opponents of expensing options argue that options are hard to value, do not represent a cash expense, andperhaps most important, especially in the high-tech sector-would cause companies to scale back option-based pay. According to venture capitalists John Doerr and Frederick Smith, "Counting options as an expense would actually distort and confuse the picture considerably. It could also prevent millions of workers from sharing in the success of their firms through employee ownership." 41

But none of this alters the reality that options represent a real cost to shareholders, and that treating one type of costly compensation instrument as "free" while expensing others creates an uneven playing field that distorts executive (and employee) pay practices. The current accounting controversy raises the possibility that options are also being overused for rank-and-file employees. U.S. companies have increasingly pushed their option plans lower into the

\footnotetext{
40 Quinn, B., "Letters to the Editor: Stock Options: Heads We Win, Tails You Lose," The Wall Street Journal, April 19, 2002.

${ }^{41}$ John D. Doerr and Frederick W. Smith, “Leave Options Alone,” New York Times, April 5, 2002.
} 
organization. As mentioned earlier, a recent study by William M. Mercer found that about $40 \%$ of all large companies have granted options to at least half of their employees, a more than doubling from the early 1990s. Moreover, a high percentage of options — about two-thirds according to one study ${ }^{42}$ - are held by non-executive employees.

Although options clearly help firms attract and retain employees (option fragility notwithstanding), the evidence that broad-based plans are effective in increasing firm performance is at best mixed. ${ }^{43}$ While a broad-based option plan has the advantage of reminding employees that the firm has owners, and perhaps contributes to an "ownership culture," such plans are a fairly blunt incentive instrument. From the perspective of any one worker in a very large company, the connection between effort and value is fairly small and likely to be swamped by other factors. The fact that broad-based option plans are not a very targeted incentive device, combined with the low value/cost efficiency of options, suggests that options are being used too heavily in broad-based compensation plans, and that companies should consider making greater use of restricted stock and cash-based compensation.

\section{CONCLUSION}

There has been a dramatic rise in equity-based pay during the past two decades. When structured properly, equity pay can add value by aligning the incentives of managers and shareholders while attracting and retaining qualified executives. But it is not at all clear that equity pay has been well structured, especially given its uneven accounting treatment, which may well have created a value-destroying bias in favor of options and against cash, stock, and other forms of compensation. ${ }^{44}$ Without rules that level the accounting playing field between options and other forms of pay, it is difficult to know the extent of this bias or how much corporate value, if any, is being destroyed.

In the coming years, new rules and regulations, and perhaps changes in corporate governance, may slow or even reverse the growth in equity-based pay for executives. But while

\footnotetext{
42 John E. Core and Wayne R. Guay, "Stock Option Plans for Non-executive Employees," Journal of Financial Economics, Vol. 61 (2001), pp. 253-287.

${ }^{43}$ See Core and Guay (2001), cited above; Richard A. Lambert, David F. Larcker, and Christopher D. Ittner, "The Structure and Performance Consequences of Equity Grants to Employees of New Economy Firms," Working Paper, University of Pennsylvania, January 2001; and Simi Kedia and Abon Mozumdar, "Performance Impact of Employee Stock Options," Harvard Business School Working Paper, August 2002, for evidence.

${ }^{44}$ Brian J. Hall and Kevin J. Murphy, "Expense Options to Level the Playing Field," Boston Globe, October 6, 2002.
} 
the form of equity pay may change, the large and growing influence of institutional investors likely to ensure that equity-based pay remains a significant component of executive compensation in the U.S. during the next decade. For good reasons, owners want managers to hold equity. Thus, although some of the methods have been called into question, the goal of creating ownership incentives is unlikely to disappear. The challenge that remains is curbing pay excesses while experimenting with new (and old) ways of linking executive rewards and long-run value creation.

BRIAN HALL is Professor of Business Administration at the Harvard Business School. 


\section{References}

Aggarwal, R.K. and A.A. Samwick, 1999, "The Other Side of the Trade-off: The Impact of Risk on Executive Compensation," Journal of Political Economy 107(1).

Antle, R. and J.S. Demski, 1988, "The Controllability Principle in Responsibility Accounting," Accounting Review 63(4), 700-716.

Antle, R. and A. Smith, 1986, "An Empirical Investigation of the Relative Performance Evaluation of Corporate Executives," Journal of Accounting Research 24(1), 1-39.

Baker, G.P. and B.J. Hall, 2001, “CEO Incentives and Firm Size.” HBS Working Paper and NBER Working Paper W6868 (December 1998).

Baker, G.P. and G.D. Smith, 1998, The New Financial Capitalists: Kohlberg Kravis Roberts and the Creation of Corporate Value. Cambridge University Press.

Baumol, W.J. and B.G. Malkiel, "Stock Options Keep the Economy Afloat," Wall Street Journal, April 4, 2002.

Bebchuk, L.A., J.M. Fried and D.I. Walker, 2002 "Managerial Power and Rent Extraction in the Design of Executive Compensation," University of Chicago Law Review 69 (3), 751-846.

Berle, A.A., Jr. and G.C. Means, 1932, The Modern Corporation and Private Property, New York: Macmillan.

Bizjak, J.M., M.L. Lemmon and L. Naveen, 2000, "Has the Use of Peer Groups Contributed to Higher Levels of Executive Compensation?” Draft.

Black, F. and M. Scholes, 1973, "The Pricing of Options and Corporate Liabilities," Journal of Political Economy 81 (May-June), 637-654.

Bushman, R.M. and A.J. Smith, April 2001, "Financial Accounting Information and Corporate Governance," Working Paper.

Carpenter, J.N., 2000. “Does Option Competition Increase Managerial Risk Appetite?" Journal of Finance 55 (5).

Carpenter, J.N. and B. Remmers, November 28, 2000. "Executive Stock Option Exercises and Inside Information," New York University Working Paper.

Cohen R. and B.J. Hall, 2002, “The Effect of Stock Options on Executive Risk-Taking,” Working Paper.

Core, J.E., W.R. Guay and R.E. Verrecchia, 2000, “Are Performance Measures Other than Price Important to CEO Incentives?" Draft.

Core, J.E. and W.R. Guay, 2001, "Stock Option Plans for Non-executive Employees," Journal of Financial Economics, August.

Core, J.E., R.W. Holthausen and D.F. Larcker, 1999, "Corporate Governance, CEO Compensation, and Firm Performance," Journal of Financial Economics 51, 371-406.

Core, J.E. and D.F. Larcker, 2002, "Performance Consequences of Mandatory Increases in Executive Stock Ownership," Journal of Financial Economics 63 (3), 315-40.

Cotter, J. F. and M. Zenner, 1994, "How Managerial Wealth Affects the Tender Offer Process," Journal of Financial Economics 35, 63-86.

Doerr, J.D. and F.W. Smith, “Leave Options Alone,” New York Times, April 5, 2002. 
Esty, B.C., 1997, "Organizational Form and Risk Taking in the Savings and Loan Industry," Journal of Financial Economics.

Esty, B.C., 1998, “The Impact of Contingent Liability on Commercial Bank Risk Taking," Journal of Financial Economics.

Gibbons, R. and K.J. Murphy, 1990, "Relative Performance Evaluation for Chief Executive Officers," Industrial and Labor Relations Review 43(3), 30s-51s.

Gompers, P.A. and A. Metrick, 2001, “Institutional Investors and Equity Prices,” Quarterly Journal of Economics 116 (1).

Hall, B.J., 2002, “Ownership Incentives and Societal Value Creation,” HBS Draft Note.

Hall, B.J., "What You Need to Know About Stock Options," 2000, Harvard Business Review, March-April 2000.

Hall, B.J., 1999, “The Design of Multi-year Stock Option Plans,” Journal of Applied Corporate Finance 12.

Hall, B.J., “Exercise on Employee Stock Option Dilution,” HBS No. 902-162.

Hall, B.J., "Incentive Strategy Within Organizations,” HBS No. 902-131.

Hall, B.J., "Incentive Strategy II: Executive Compensation and Ownership Structure," HBS No. 902-134.

Hall, B.J., R. Khurana and C. Madigan, “Al Dunlap at Sunbeam,” HBS No. 899-218.

Hall, B.J. and R. Khurana, 2002, “International Executive Succession and Compensation,” Draft.

Hall, B.J. and T.A. Knox, 2002, “Managing Option Fragility,” HBS Working Paper.

Hall, B.J. and J.B. Liebman, 1998, “Are CEOs Really Paid Like Bureaucrats?” Quarterly Journal of Economics 113 (3).

Hall, B.J. and J.B. Liebman, 2000, "The Taxation of Executive Compensation," in Tax Policy and the Economy, NBER volume edited by J. Poterba, MIT Press, Vol. 14.

Hall, B.J., H. Lane and J.P. Lim, “Akamai’s Underwater Options (A),” HBS No. 902-069.

Hall, B.J., H. Lane and J.P. Lim, “Akamai’s Underwater Options (B): The Decision,” HBS No. 902-195.

Hall, B.J. and C. Madigan, "Gerald Weiss,” HBS No. 899-258.

Hall, B.J., C. Madigan and N. Wasserman, "Stock Options at Virtua.Net,” HBS No. 801-324.

Hall, B.J. and K.J. Murphy, 2002a, “Stock Options for Undiversified Executives,” Journal of Accounting and Economics.

Hall, B.J. and K.J. Murphy, 2002b, "Expense Options to Level the Playing Field," Boston Globe, Oct. 6.

Hall, B.J. and K.J. Murphy, 2001, “Option Value Does Not Equal Option Cost,” WorldAtWork Journal, Second Quarter 2001.

Hall, B.J. and K.J. Murphy, 2000, "Optimal Exercise Prices for Executive Stock Options," American Economic Review.

Hall, B.J., C. Rose and G. Subramanian, “Circon (A),” HBS No. 801-403.

Hall, B.J., P. Tufano and J. Musher, "Sara’s Options,” HBS No. 201-005. 
Jensen, M.C. and E.F. Fama, 1994, "Separation of Ownership and Control." In Management of Non-profit Organizations, edited by S. M. Oster. Dartmouth Publishing. (Also published in Journal of Law and Economics 26(2) (June, 1983) and M.C. Jensen, Foundations of Organizational Strategy, Harvard University Press, 1998.

Jensen, M.C. and W.H. Meckling, 1976, "Theory of the Firm: Managerial Behavior, Agency Costs, and Ownership Structure," Journal of Financial Economics 3, 305-360.

Jensen, M.C. and K.J. Murphy, 1990a, "Performance Pay and Top-management Incentives," Journal of Political Economy 98(2), 225-64.

Jensen, M.C. and K.J. Murphy, 1990b, "CEO Incentives-It's Not How Much You Pay, But How," Harvard Business Review (May).

Johnson, S.A and Y.S. Tian, 2000, "Indexed Executive Stock Options," Journal of Financial Economics 57.

Kedia, S. and A. Mozumdar, 2002. "Performance Impact of Employee Stock Options," HBS Draft, January.

Khanna, T. and K. Palepu, 2000a, "Is Group Affiliation Profitable in Emerging Markets? An Analysis of Diversified Indian Business Groups," Journal of Finance 55 (2).

Khanna, T. and K. Palepu, 2000b, "The Future of Business Groups in Emerging Markets: LongRun Evidence from Chile," Academy of Management Journal 43 (3).

Khurana, R., 2002, Searching for a Corporate Savior: Charisma, Closure and Market Failure in the CEO Labor Market. Princeton, NJ: Princeton University Press.

Lambert, R.A., W. Lanen, and D. Larcker, 1989, "Executive Stock Options and Corporate Dividend Policy," Journal of Financial and Quantitative Analysis 24(4), 409-425.

Lambert, R.A., D.F. Larcker and C.D. Ittner, 2001, "The Structure and Performance Consequences of Equity Grants to Employees of New Economy Firms," Draft.

Lambert, R.A., D.F. Larcker and R.E. Verrecchia, 1991, "Portfolio Considerations in Valuing Executive Compensation." Journal of Accounting Research 29 (1).

Lewellen, W., C. Loderer, and A. Rosenfeld, 1985, "Merger Decisions and Executive Stock Ownership in Acquiring Firms," Journal of Accounting and Economics 7, 209-31.

Loderer, C. and K. Martin, 1997, "Executive Stock Ownership and Performance: Tracking Faint Traces," Journal of Financial Economics 45, 223-56.

Lorsch, J.W., 1998, “Compensating CEOs: A Process View,” Working Paper 99-013.

McConnell, J. and H. Servaes, 1990, "Additional Evidence on Equity Ownership and Corporate Value," Journal of Financial Economics 27, 595-612.

Mehran, H., 1995, "Executive Compensation Structure, Ownership, and Firm Performance," Journal of Financial Economics 38, 163-184.

Merton, R.C., 1973, “Theory of Rational Option Pricing,” Bell Journal of Economics and Management Science 4, 141-183.

Meulbroek, L.K., 2001a, "Restoring the Link Between Pay and Performance: Evaluating the Costs of Relative-Performance-Based (Indexed) Options,” HBS Working Paper 02-021.

Meulbroek, L.K., 2001b, "Designing an Option Plan that Rewards Relative Performance: Indexed Options Revisited,” HBS Working Paper 02-022 (September 2001). 
Meulbroek, L.K., 2001c, “The Efficiency of Equity-linked Compensation: Understanding the Full Cost of Awarding Executive Stock Options," Financial Management 30(2), 5-30.

Maremont, M., “Tyco CEO’s Stock Options Yield \$99.9 Million Gain,” Wall Street Journal, January 30, 2001.

Morck, R., A. Shleifer, and R. Vishny, 1988, "Management Ownership and Market Valuation: An Empirical Analysis," Journal of Financial Economics 20, 293-316.

Murphy, K.J., 1999, "Executive Compensation," Handbook of Labor Economics, Vol. 3, edited by O. Ashenfelter and D. Card.

Murphy, K.J. and J. Dial, “General Dynamics: Compensation and Strategy (A),” HBS No. 494048.

Quinn, B., "Letters to the Editor: Stock Options: Heads We Win, Tails You Lose," Wall Street Journal, April 19, 2002.

Rappaport, A., 1999, "New Thinking on How to Link Executive Pay with Performance," Harvard Business Review, March-April.

Roberts, G.R., 1998, “Corporate Governance and the Power of Ownership," The Corporate Board, September/October.

Salter, M.S., "Innovation Corrupted: The Rise and Fall of Enron," HBS No. 903-032.

Simons, R. 2000, Performance Measurement and Control Systems for Implementing Strategy. Upper Saddle River, NJ: Prentice Hall.

Smith, A., 1937, Wealth of Nations (1776; ed. E. Cannan, 1904). Reprint: New York, NY: Modern Library.

Tufano, P., 1996, "Who Manages Risk? An Empirical Examination of Risk Management Practices in the Gold Mining Industry," Journal of Finance 51 (4).

Welch, J. with J.A. Byrne, 2001, Jack: Straight from the Gut, New York: Warner Books.

Yermack, D., 1997, "Good Timing: CEO Stock Option Awards and Company News Announcements," Journal of Finance 52 (2). 